\title{
Nitric Oxide/Cyclic GMP Pathway Attenuates ATP-Evoked Intracellular Calcium Increase in Supporting Cells of the Guinea Pig Cochlea
}

\author{
TAKESHI MATSUNOBU AND JOCHEN SCHACHT* \\ Kresge Hearing Research Institute, University of Michigan, Ann Arbor, \\ Michigan 48109-0506
}

\begin{abstract}
We demonstrate here that nitric oxide (NO) attenuates ATP-evoked calcium transients in Deiters' and Hensen's cells, "supporting" (nonsensory) cells of the guinea pig cochlea, by means of activation of soluble guanylyl cyclase and protein kinase G. The enzymatic activities associated with the nitric oxide/cGMP/protein kinase G pathway had previously been demonstrated to be present in Deiters' and Hensen's cells. We now isolate these cells and measure changes in intracellular free calcium by using the calcium indicator fluo-3. In Deiters' cells, calcium increased rapidly in response to the application of ATP. The increase was attenuated when the pathway was stimulated by NO donors (diethylamine NONOate or sodium nitroprusside) or the cyclic GMP analog, 8-bromo-cyclic GMP. When the activation of the pathway was blocked by the additional presence of inhibitors of soluble guanylyl cyclase (LY83583) or protein kinase G (Rp-8-bromo-cyclic GMP or KT5823), the response to ATP was restored. The reactions also occurred in calcium-free media. Hensen's cells responded similarly. These results provide evidence that intracellular calcium is regulated by the NO/cGMP/protein kinase G pathway in the inner ear. J. Comp. Neurol. 423:452-461, 2000. $\odot 2000$ Wiley-Liss, Inc.
\end{abstract}

Indexing terms: Deiters' cell; Hensen's cell; calcium homeostasis; soluble guanylyl cyclase; protein kinase $\mathbf{G}$

A variety of external stimuli may evoke temporally and spatially organized fluctuations of the intracellular calcium concentration $\left[\mathrm{Ca}^{2+}\right]_{\mathrm{i}}$. Such calcium signals can be triggered by neurotransmitter/receptor interactions mediating $\mathrm{Ca}^{2+}$ entry through ligand-gated channels or $\mathrm{Ca}^{2+}$ release from intracellular stores (Berridge, 1998; Berridge et al., 1999). In mammalian cochlear sensory cells, the hair cells, stimulation by neurotransmitters or neuromodulators such as acetylcholine or adenosine $5^{\prime}$ triphosphate (ATP) results in the elevation of $\left[\mathrm{Ca}^{2+}\right]_{\mathrm{i}}$ (Ashmore and Ohmori, 1990; Doi and Ohmori, 1993; Dulon et al., 1993, Sugasawa et al., 1996). Similarly, nonsensory "supporting cells" (Deiters' cells, Hensen's cells) respond to ATP (Dulon et al., 1993; Sugasawa et al., 1996). Although their role in cochlear physiology is not clear, these supporting cells may participate in the modulation of auditory transduction (Fridberger et al., 1998; Flock et al., 1999).

Despite an equal importance for the control of calcium signaling, little is known about dynamic processes for the attenuation of $\left[\mathrm{Ca}^{2+}\right]_{i}$ in the mammalian cochlea.
We recently have suggested the involvement of the nitric oxide/guanosine $3^{\prime}, 5^{\prime}$-cyclic monophosphate/cyclic GMP-dependent protein kinase pathway (NO/cGMP/cGK pathway) in the regulation of cochlear blood flow and supporting cell physiology (Fessenden et al., 1994, Fessenden and Schacht, 1997, 1998, Tian et al., 1999). The pathway has also been described in other sensory systems, namely in vision (Ahmad and Barnstable, 1993; Yamamoto et al., 1993; Cudeiro and Rivadulla, 1999) and olfaction (Dellacorte et al., 1995). In a variety of cell types,

Grant sponsor: National Institutes of Deafness and Other Communication Disorders, National Institutes of Health; Grant number: DC-02982.

Dr. Matsunobu's permanent address is: Department of Otolaryngology, School of Medicine, Keio University, Tokyo, Japan.

*Correspondence to: Jochen Schacht, Kresge Hearing Research Institute, University of Michigan, Ann Arbor, MI 48109-0506.

E-mail: schacht@umich.edu

Received 13 December 1999; Revised 28 March 2000; Accepted 28 March 2000 
it may modulate calcium homeostasis, primarily through the phosphorylation of specific target proteins by cGK. For example, in smooth muscle NO elevates cyclic GMP and inhibits $\left[\mathrm{Ca}^{2+}\right]_{\mathrm{i}}$ increases in response to agonists thereby causing relaxation (Felbel et al., 1988; Karaki et al., 1988; Cornwell and Lincoln, 1989; Shah et al., 1994; Kannan et al., 1997). Such inhibition of $\left[\mathrm{Ca}^{2+}\right]_{i}$ responses may be based on a reduction in $\mathrm{Ca}^{2+}$ influx, stimulation of $\mathrm{Ca}^{2+}$ efflux, inhibition of intracellular $\mathrm{Ca}^{2+}$ release, or stimulation of intracellular $\mathrm{Ca}^{2+}$ uptake (Clementi, 1998). In this study, we investigate the relationship between the NO/cGMP/cGK pathway and calcium homeostasis in isolated supporting cells of the guinea pig.

\section{MATERIALS AND METHODS Cell preparation}

Pigmented adult guinea pigs (200-350 g) were anesthetized with $\mathrm{CO}_{2}$ and decapitated; the bullae were quickly removed and placed in Hanks' balanced salt solution (HBSS: $1.25 \mathrm{mM} \mathrm{CaCl}, 5.55 \mathrm{mM}$ glucose, $0.81 \mathrm{mM}$ $\mathrm{MgSO}_{4}, 0.44 \mathrm{mM} \mathrm{KH} \mathrm{PO}_{4}, 136.9 \mathrm{mM} \mathrm{NaCl}, 0.34 \mathrm{mM}$ $\mathrm{Na}_{2} \mathrm{H}_{2} \mathrm{PO}_{4}, 5.4 \mathrm{mM} \mathrm{KCl}, 5.0 \mathrm{mM}$ sodium HEPES, with osmolality adjusted to $300 \pm 2 \mathrm{mOsm}$ (with $\mathrm{NaCl}$ ) and $\mathrm{pH}$ to 7.4). The bony wall of the cochlea was immediately opened. After detaching the stria vascularis and the tectorial membrane, the organ of Corti (mostly from the apical and middle turns of the cochlea) was separated from the spiral lamina with a fine metal probe and cells were dissociated essentially as described for the isolation of outer hair cells (Zenner et al., 1985; Zajic and Schacht, 1987). Dissected strips of the organ of Corti were transferred into a $50-\mu l$ droplet of HBSS. A 50- $\mu$ l aliquot of collagenase type IV ( $1 \mathrm{mg} / \mathrm{ml}$ HBSS) was added and the strips were incubated for 20 minutes at room temperature $\left(22-25^{\circ} \mathrm{C}\right)$. The strips were then transferred into a $50-\mu \mathrm{l}$ droplet of HBSS on a glass coverslip sealed in the middle of a perforated Petri dish. The isolation was completed by gentle influx and efflux of the tissue pieces through a micropipette. The cells were allowed to settle onto the coverslip for 30 minutes before all experiments.

\section{Calcium imaging}

One-millimolar stock solutions of the permeant acetoxy methyl ester derivative of fluo-3, fluo-3/AM, were prepared in dry dimethyl sulfoxide (DMSO) and stored below $0^{\circ} \mathrm{C}$. For dye loading, cells were incubated for 30 minutes at room temperature with fluo-3/AM diluted in HBSS to a final concentration of $2 \mu \mathrm{M}$. They were finally carefully rinsed with HBSS and maintained in a 50- $\mu$ l droplet of HBSS on glass coverslips in a saturated humid chamber.

Cells loaded with fluo-3/AM were observed with an inverted microscope (Leitz Fluovert FS) fitted with an epifluorescence system (ArcLamp HBO $100 \mathrm{~W}$, a 450- to 490-nm band pass exciter filter, 510-nm dichroic mirror for excitation, and a 520-nm barrier filter for emission) and Nikon objectives (Plan A+ 60/1.4 oil, Fluor 100/1.3 oil). To prevent photo bleaching, the excitation irradiance was reduced $97.5 \%$ by a combination of neutral density filters. No significant photo bleaching was noted with continuous illumination of up to 2 minutes, the maximal exposure time in this study.

Cell fluorescence was monitored by means of a Silicon Intensified Target camera (SIT 66, Dage-MTI, Inc., Mich-

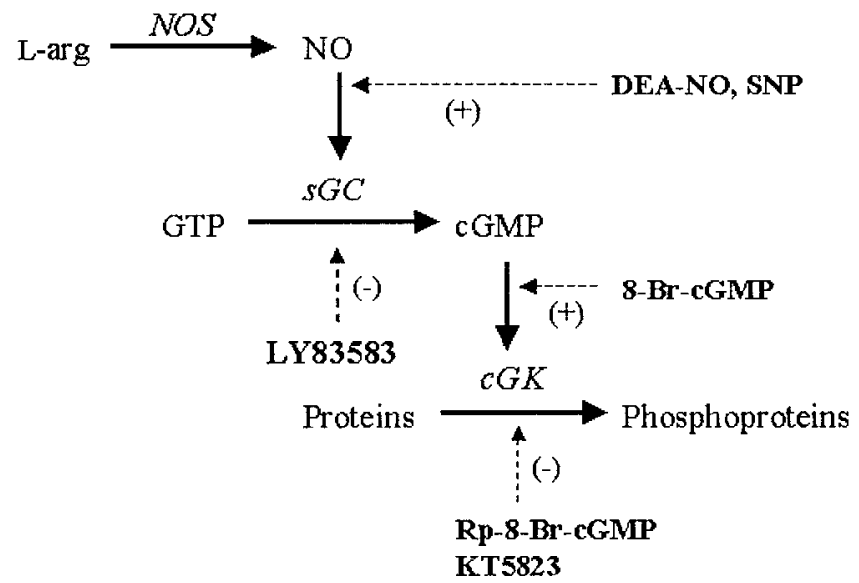

Fig. 1. Site of action of agents used in this study. The nitric oxide/guanosine $3^{\prime}, 5^{\prime}$-cyclic monophosphate/cyclic GMP-dependent protein kinase pathway (NO/cGMP/cGK pathway; schematically outlined) consists of the enzymes nitric oxide synthase (NOS), soluble guanylyl cyclase (sGC) and protein kinase $\mathrm{G}$ (cGK). It is stimulated by diethylamine NONOate (DEA-NO) or sodium nitroprusside (SNP) supplying NO or by 8-bromo-cyclic GMP (8-Br-cyclic GMP) mimicking cyclic GMP. It is attenuated by LY83583 (inhibitor of sGC), Rp-8-Brcyclic GMP (cGMP antagonist), or KT5823 (inhibitor of cGK).

igan City, IN), and the recorded images were analyzed with Axon Workbench 2.1 software (Axon Instruments, Inc., Foster City, CA). Frames were acquired at a rate of 32 frames/1.066 second with an image size of $640 \times 480$ pixels. Sixteen to 32 sequential frames from the camera were averaged, and fluorescence intensity of the cell images was determined by averaging the pixel radiance value of the cell after subtracting background fluorescence.

The relation between $\left[\mathrm{Ca}^{2+}\right]_{\mathrm{i}}$ and fluorescence intensities of fluo-3 was determined by a combined in vivo and in situ calibration as described in detail previously (Dulon et al., 1990) using calcium-buffered standards and fluo-3 pentapotassium salt (Molecular Probes, Inc., St. Louis, MO).

\section{Application of ATP}

The cells were stimulated by a short ( 2 seconds) puff of ATP applied by a pressure puff ejector (PLI-100, Medical Systems Corp., Greenvale, NY) by means of a glass pipette (opening, $0.5 \pm 0.2 \mu \mathrm{m}$; Sterile Femtotips, Eppendorf Scientific, Westbury, NY). The pipette was held approximately $50 \mu \mathrm{m}$ away from the base of the cell. Experiments with fluorescent dyes showed that the ejected puff reached a maximum around the cell within 1 second and was then rapidly diluted in the medium. Concentrations of ATP are stated as concentrations in the pipette.

\section{Application of other agents}

Stock solutions of other reagents were applied in $5-\mu l$ aliquots to the $50-\mu l$ droplet containing the cells. Sodium nitroprusside (SNP), diethylamine NONOate (DEA-NO), and 8-bromo-cyclic GMP (8-Br-cyclic GMP) were dissolved in HBSS, pH 7.4. KT5823 and LY83583 were dissolved in DMSO and diluted in HBSS to obtain the stock solution. The drugs used to probe the NO/cyclic GMP pathway and their site of action are summarized in Figure 1. 

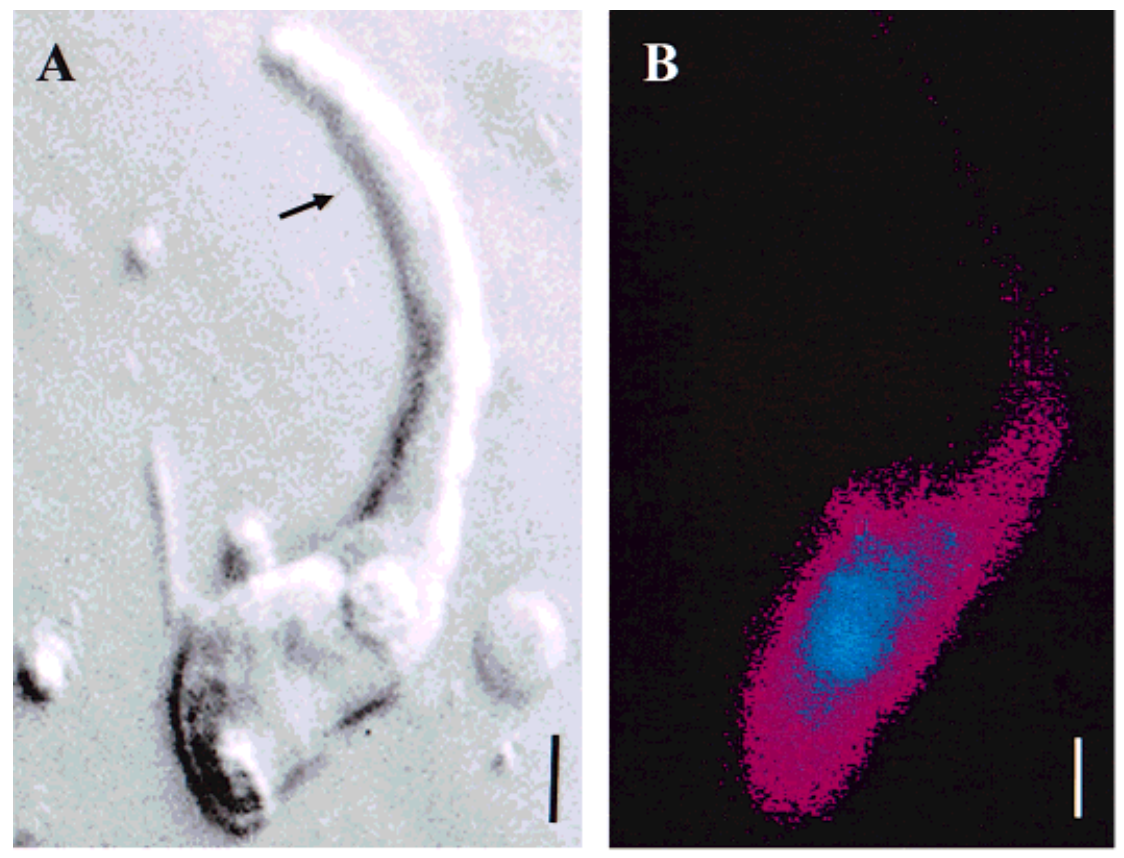

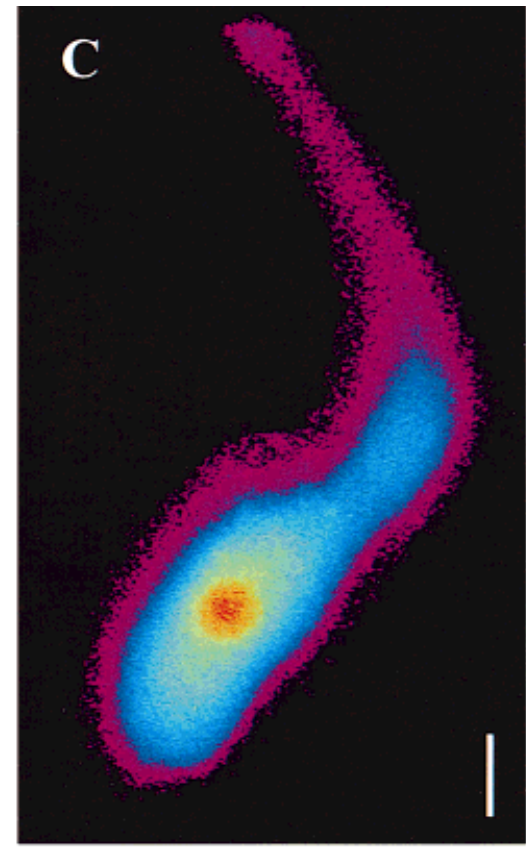

0
Fig. 2. Calcium imaging in Deiters' cells. A: Brightfield photomicrograph of an isolated Deiters' cell of the guinea pig cochlea. Deiters' cells are easily identified by their unique phalangeal processes (arrow). B,C: Fluorescence images of the same cell at rest (B) and at the

\section{Data analysis}

The amplitude of an evoked response is defined as the difference $\left(\mathrm{dCa}^{2+}\right)$ between the stimulated $\left[\mathrm{Ca}^{2+}\right]_{\mathrm{i}}$ and the cell's resting level of $\left[\mathrm{Ca}^{2+}\right]_{i}$. All values are presented as means \pm SEM. Differences between mean values were evaluated by using analysis of variance with NewmanKeuls as a post hoc test. A $P$ value of $<0.05$ was considered significant.

\section{Animal use and care}

The experimental protocols are in compliance with guidelines of the National Institutes of Health and the Declaration of Helsinki and were approved by the University of Michigan's Committee on Use and Care of Animals. Animal care was under the supervision of the University of Michigan's Unit for Laboratory Animal Medicine.

\section{Materials}

HBSS and $\mathrm{Ca}^{2+}$-free HBSS were purchased from Gibco (Grand Island, NY), fluo-3 pentapotassium salt and fluo3/AM from Molecular Probes, Inc. (Eugene, OR). DEA-NO was obtained from Cayman Chemical (Ann Arbor, MI). When indicated, DEA-NO was depleted of NO by acidification to $\mathrm{pH} 4$, bubbling with nitrogen for 1 hour, and readjustment of the $\mathrm{pH}$ to 7.4 with $\mathrm{NaOH}$. $\mathrm{Rp}$-8-bromocyclic GMP, KT5823, and LY83583 were from Biomol Research Laboratories, Inc. (Plymouth Meeting, PA). All other reagents were obtained from Sigma Chemical Co. peak of the ATP response (C). Levels of $\left[\mathrm{Ca}^{2+}\right]_{\mathrm{i}}$ are displayed in pseudocolors. Calibration ramp: fluorescence intensity in arbitrary units. Scale bar $=10 \mu \mathrm{m}$ in A-C.

\section{Cell identification and viability}

In isolates of cochlear cells, Deiters' cells were distinguished from other cells types by their typical phalangeal processes (Fig. 2A). They maintained morphologic integrity for approximately 4 hours post mortem as judged by light microscopic inspection. Initial resting levels of $\left[\mathrm{Ca}^{2+}\right]_{\mathrm{i}}$ were $56 \pm 5 \mathrm{nM}(\mathrm{n}=15)$ and slowly increased with time at a rate of approximately $20 \mathrm{nM} / \mathrm{hr}$. Responses to stimuli could still be observed after 5 hours. However, all experiments reported here were conducted within 1 hour after cell isolation.

Responses to extracellular ATP were similar whether cells were isolated by enzymatic treatment or mechanical disruption only (data not shown). Enzymatic isolation was preferred because of a more consistent yield of isolated cells. By using collagenase, the average number of Deiters' cells obtained after the complete procedure was 10 cells per cochlea.

The Hensen's cells, which form a group of supporting cells outside the outer tunnel of the organ of Corti, were identified by the presence of lipid inclusions in their cytosol (Fig. 3A). They were seen as single cells or, more frequently, as small clusters of two to three cells. The yield from one cochlea was approximately 20 cells, which remained viable for approximately 5 hours.

Outer hair cells constituted the bulk of the preparation. They were easily distinguished by their cylindrical shape, 

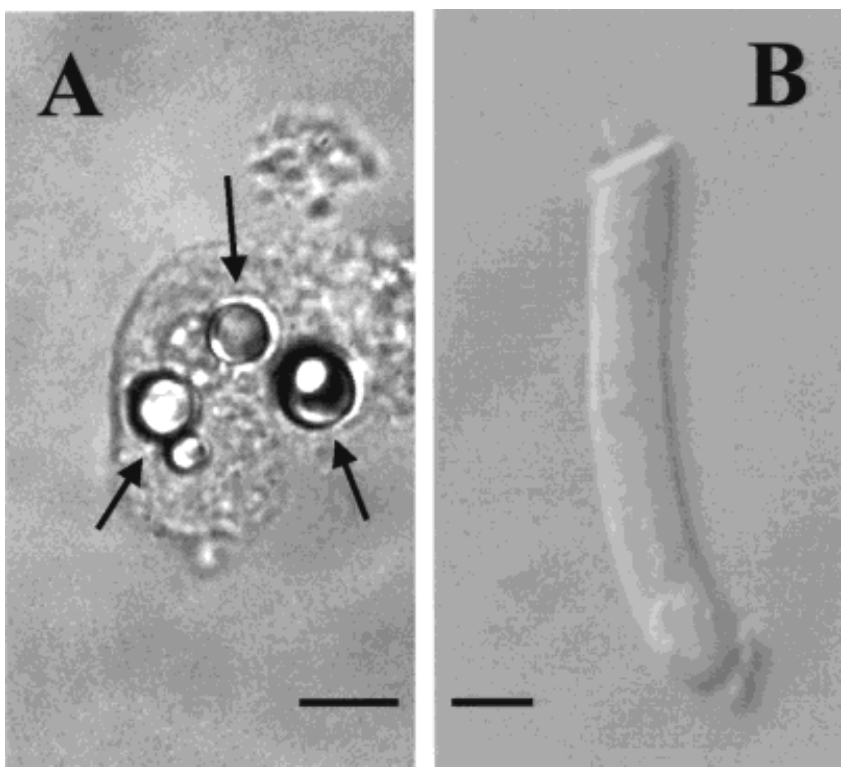

Fig. 3. Other types of isolated cochlear cells. A: Brightfield micrograph of an isolated Hensen's cell, which is identified by its distinct lipid droplets in the cytoplasm (arrows). B: Brightfield photomicrograph of an isolated outer hair cell. Outer hair cells show a cylindrical shape, tufts of stereocilia at their apex, and a low-positioned nucleus. Scale bar $=10 \mu \mathrm{m}$ in A,B.

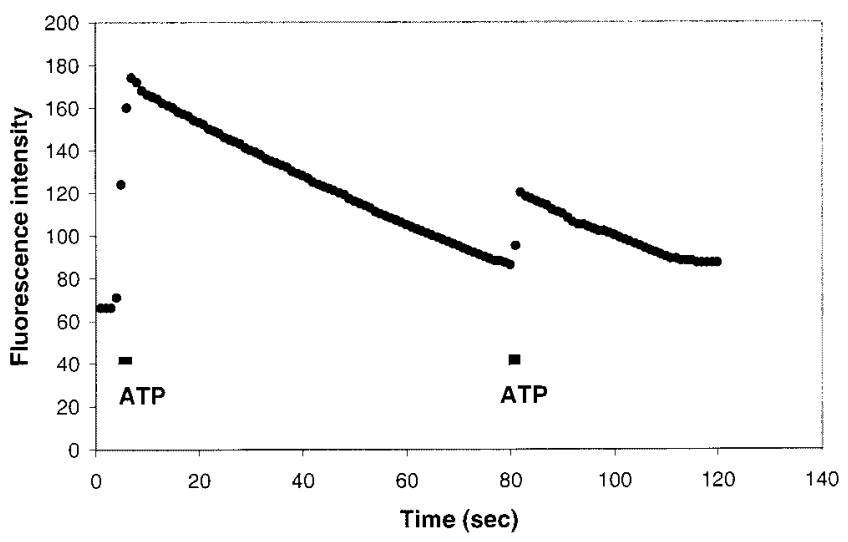

Fig. 4. ATP evokes transient $\left[\mathrm{Ca}^{2+}\right]_{\mathrm{i}}$ increases in Deiters' cells. A typical response of a Deiters' cells to a repeated bolus application of ATP $(100 \mu \mathrm{M})$ is shown. Fluorescence intensity of the calcium indicator fluo-3 is given in arbitrary units.

low-positioned nucleus, and tufts of stereocilia at their apical end (Fig. 3B; Zajic and Schacht, 1985).

\section{ATP-evoked increases of $\left[\mathrm{Ca}^{2+}\right]_{i}$ in calcium- containing media}

ATP-evoked increases of $\left[\mathrm{Ca}^{2+}\right]_{i}$ in Deiters' cells. Deiters' cells responded to the application of ATP with an increase in $\left[\mathrm{Ca}^{2+}\right]_{\mathrm{i}}$ (Fig. 2B,C). A bolus of $100 \mu \mathrm{M}$ ATP evoked a transient response (Fig. 4) that could be triggered repeatedly. However, the amplitude of the subsequent responses gradually decreased, and only the first $\mathrm{Ca}^{2+}$ response was considered in our experiments.

The amplitude depended on the ATP concentration and reached a maximum at $100 \mu \mathrm{M}$ ATP in the puff pipette

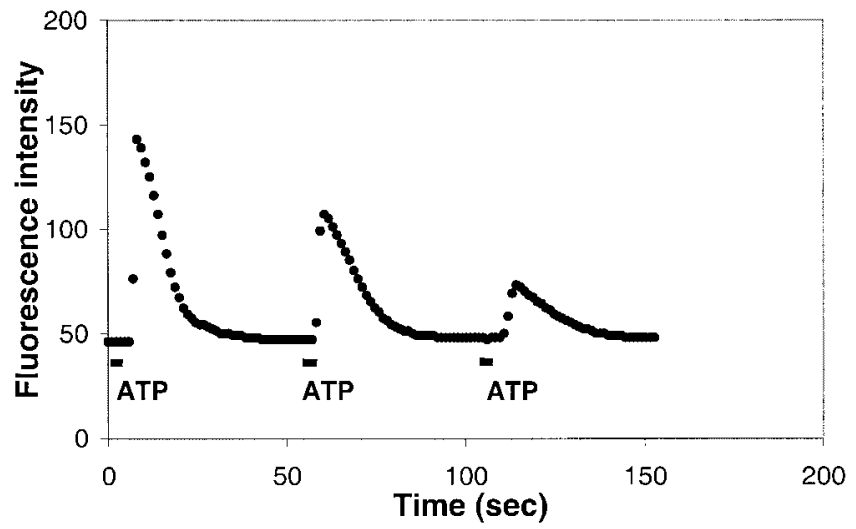

Fig. 5. ATP-evoked $\left[\mathrm{Ca}^{2+}\right]_{\mathrm{i}}$ increases in Hensen's cells. A typical response of a Hensen's cell to bolus applications of ATP $(100 \mu \mathrm{M})$ is shown. Fluorescence intensity of the calcium indicator fluo-3 is given in arbitrary units.

(data not shown) in agreement with earlier studies by Dulon et al. (1993). At this concentration, $\left[\mathrm{Ca}^{2+}\right]_{\mathrm{i}}$ increased from $56 \mathrm{nM}$ to $313 \mathrm{nM}(\mathrm{n}=15, P<0.01)$. After a puff of 2 seconds duration, responses of individual cells reached their maximum within 10 seconds. Thereafter, $\left[\mathrm{Ca}^{2+}\right]_{i}$ decreased with a mean half-life of 1 to 2 minutes, indicating that calcium buffering or sequestering mechanisms were active in the cell.

Application of control solutions (HBSS alone or with the vehicles used for the subsequently tested agents) did not cause any significant changes in $\left[\mathrm{Ca}^{2+}\right]_{i}$. Likewise, the presence of vehicles did not affect the time course or the magnitude of the cellular reaction to ATP. For example, the amplitude of the ATP response was $259 \pm 41(\mathrm{n}=15)$ in HBSS compared with $240 \pm 27(\mathrm{n}=11)$ in HBSS with DMSO.

ATP-evoked increases of $\left[\mathrm{Ca}^{2+}\right]_{i}$ in Hensen's cells. Hensen's cells also responded to the application of ATP with an increase in $\left[\mathrm{Ca}^{2+}\right]_{i}$. A bolus of $100 \mu \mathrm{M}$ ATP evoked a transient response in eight of eight cells, which could be triggered repeatedly (Fig. 5). The amplitude of the subsequent responses gradually decreased in a manner similar to that in Deiters' cells, and only the first response was selected for further study.

As in Deiters' cells, the amplitude of the increase in $\left[\mathrm{Ca}^{2+}\right]_{\mathrm{i}}$ was dose-dependent and maximal at $100 \mu \mathrm{M}$ ATP (data not shown), a result again in agreement with earlier studies by Dulon et al. (1993). At this ATP concentration, $\left[\mathrm{Ca}^{2+}\right]_{\mathrm{i}}$ increased from $33 \mathrm{nM}$ to $323 \mathrm{nM}(\mathrm{n}=8, P<0.01)$. After a puff of 2 seconds duration, responses of individual cells reached their maximum within 5 seconds. Thereafter, $\left[\mathrm{Ca}^{2+}\right]_{\mathrm{i}}$ decreased considerably more rapidly than in Deiters' cells with a half-life of 5 to 10 seconds. Puff application of HBSS alone $(\mathrm{n}=7)$ did not cause any significant changes in $\left[\mathrm{Ca}^{2+}\right]_{\mathrm{i}}$.

\section{ATP-evoked increases of $\left[\mathrm{Ca}^{2+}\right]_{i}$ in calcium- free media}

ATP-evoked increases of $\left[\mathrm{Ca}^{2+}\right]_{i}$ in Deiters' cells. To characterize the ATP-evoked response further, Deiters' cells were bathed in $\mathrm{Ca}^{2+}$-free HBSS (with $1 \mathrm{mM}$ ethylene glycol-bis[ $\beta$-aminoethyl ether], EGTA) 15 minutes before ATP stimulation. ATP $(100 \mu \mathrm{M})$ still evoked significant 

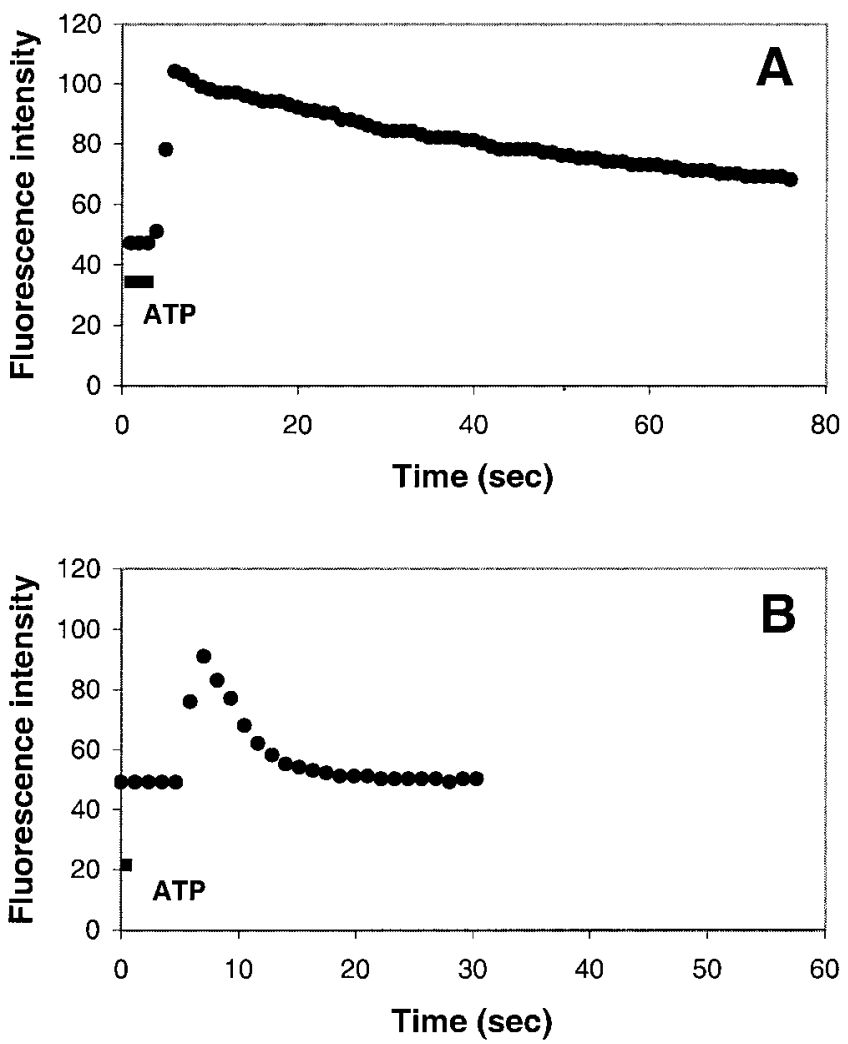

Fig. 6. ATP evokes a transient $\left[\mathrm{Ca}^{2+}\right]_{\mathrm{i}}$ increase in $\mathrm{Ca}^{2+}$-free media in Deiters' cells and Hensen's cells. A: Typical response of a Deiters' cell to a bolus application of ATP in $\mathrm{Ca}^{2+}$-free medium. The amplitude of the $\left[\mathrm{Ca}^{2+}\right]_{\mathrm{i}}$ increase is smaller than that in regular medium (Fig. 4). B: Typical response of a Hensen's cell to a bolus application of ATP in $\mathrm{Ca}^{2+}$-free medium. The amplitude of the $\left[\mathrm{Ca}^{2+}\right]_{\mathrm{i}}$ increase is smaller than that in regular medium (Fig. 5).

but reduced $\mathrm{Ca}^{2+}$-transients with an amplitude of $147 \pm$ $33 \mathrm{nM}$ (Fig. 6A).

ATP-evoked increases of $\left[\mathrm{Ca}^{2+}\right]_{i}$ in Hensen's cells. In analogous experiments, Hensen's cells were bathed in $\mathrm{Ca}^{2+}$-free HBSS (with 1 mM EGTA) before ATP stimulation. ATP $(100 \mu \mathrm{M})$ evoked $\mathrm{Ca}^{2+}$-transients in five of five cells with a reduced amplitude of $98 \pm 2 \mathrm{nM}$ (Fig. 6B).

\section{Activation of the NO/cGMP/cGK pathway attenuates ATP-evoked calcium increases in Deiter's cells}

NO donors attenuate ATP-evoked calcium increases. To investigate whether nitric oxide effected the ATPevoked increases in $\left[\mathrm{Ca}^{2+}\right]_{\mathrm{i}}$, we applied the NO donors DEA-NO and SNP (Maragos et al., 1991; Gryglewski et al., 1989). The cells were incubated with either $0.1 \mu \mathrm{M}$ DEA-NO or $100 \mu \mathrm{M}$ SNP for 30 minutes in HBSS before ATP stimulation. After treatment with DEA-NO, the amplitude of the ATP-response was significantly attenuated (Figs. 7A, $8 ; P<0.05)$ to $20 \pm 7 \mathrm{nM}(\mathrm{n}=15)$ compared with controls with ATP alone of $256 \pm 41 \mathrm{nM}(\mathrm{n}=15$, Fig. 4). Likewise, SNP reduced the amplitude of the ATP response $(P<0.05$, Fig. 9). A DEA-NO solution depleted of NO had no effect on the ATP-evoked $\left[\mathrm{Ca}^{2+}\right]_{\mathrm{i}}$ increase (Fig. 8).
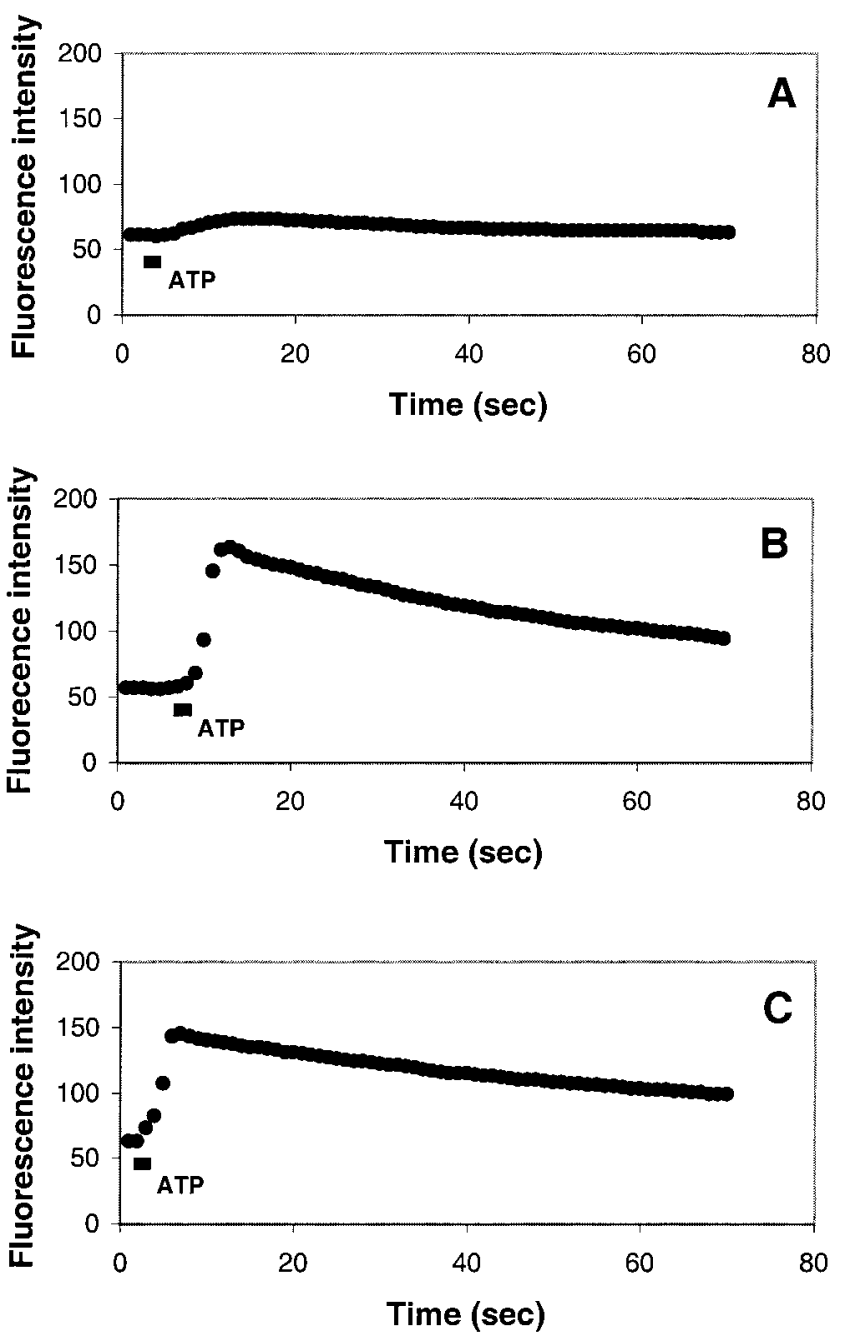

Fig. 7. Effects of DEA-NO, KT5823, and LY83583 on the ATPevoked $\left[\mathrm{Ca}^{2+}\right]_{\mathrm{i}}$ increases in Deiters' cells. A: Treatment of cells with $0.1 \mu \mathrm{M}$ DEA-NO before ATP stimulation reduced the amplitude of the ATP response. B: Treatment of cells with KT5823 (1 $\mu \mathrm{M})$ before the addition of DEA-NO $(0.1 \mu \mathrm{M})$ and ATP inhibits the action of DEA-NO. The amplitude of the ATP response is normal. (C) Treatment of cells with LY83583 $(10 \mu \mathrm{M})$ before the addition of DEA-NO $(0.1 \mu \mathrm{M})$ and ATP inhibits the action of DEA-NO. The amplitude of the ATP response is normal. For abbreviations, see legend for Figure 1.

8-Br-cyclic GMP attenuates ATP-evoked calcium increases. To investigate the participation of cyclic GMP we used a membrane-permeable cyclic GMP analogue, 8-Br-cyclic GMP (Corbin et al., 1986). The Deiters' cells were incubated in HBSS with $30 \mu \mathrm{M}$ 8-Br-cyclic GMP for 30 minutes before ATP stimulation. The amplitude of the ATP-evoked $\left[\mathrm{Ca}^{2+}\right]_{\mathrm{i}}$ response was significantly attenuated to $149 \pm 26 \mathrm{nM}(\mathrm{n}=10 ; P<0.05$, Fig. 10).

The action of 8-Br-cyclic GMP was also explored in a $\mathrm{Ca}^{2+}$-free medium. The amplitude of the response was again significantly attenuated to $60 \pm 10 \mathrm{nM}(\mathrm{n}=24)$ compared with the corresponding control value of $147 \pm$ $33 \mathrm{nM}$ for the absence of 8-Br-cyclic GMP $(\mathrm{n}=13, P<$ 0.05, Fig. 11). 


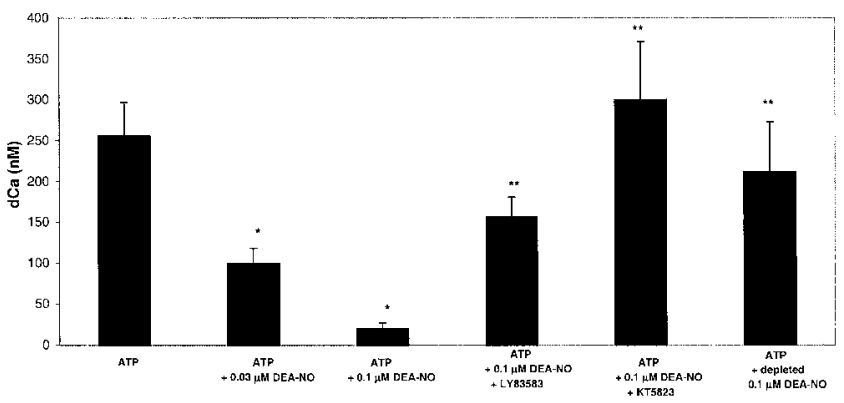

Fig. 8. Effect of stimulators and inhibitors on ATP-evoked $\left[\mathrm{Ca}^{2+}\right]_{\mathrm{i}}$ increase by DEA-NO. The response to ATP $(100 \mu \mathrm{M}, \mathrm{n}=15)$ is significantly attenuated by DEA-NO $(0.03 \mu \mathrm{M} ; \mathrm{n}=8 ; 0.1 \mu \mathrm{M}, \mathrm{n}=15)$ but not by NO-depleted DEA-NO. The suppressive effect of NO was reversed by the additional treatment with $10 \mu \mathrm{M} L Y 83583(\mathrm{n}=15)$ or KT5823 ( $1 \mu \mathrm{M}, \mathrm{n}=13)$. Data are means \pm SEM. Single asterisks indicate significantly different from the response to ATP alone $(P<$ 0.05 ). Double asterisks indicate significantly different from the response to ATP in the presence of $0.1 \mu \mathrm{M}$ DEA-NO $(P<0.05)$. For abbreviations, see legend for Figure 1.

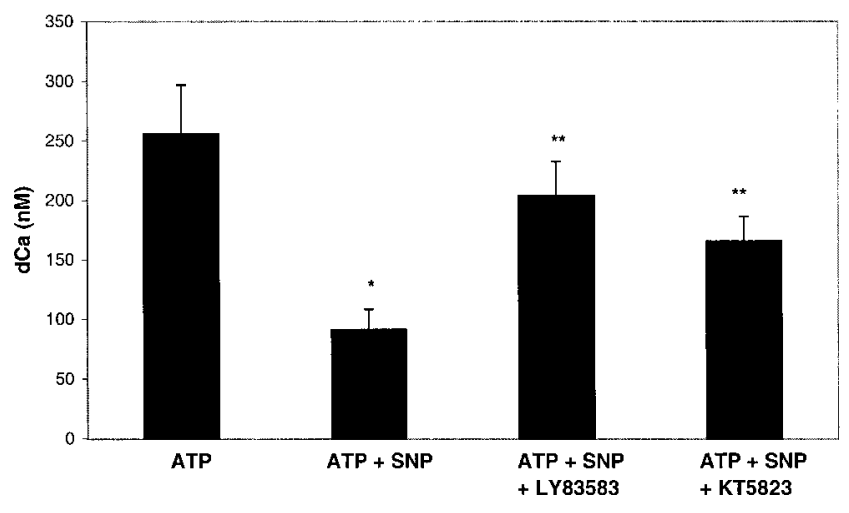

Fig. 9. Effect of LY83583 and KT5823 on the attenuation of ATPevoked $\left[\mathrm{Ca}^{2+}\right]_{\mathrm{i}}$ increases by SNP. SNP $(100 \mu \mathrm{M}, \mathrm{n}=25)$ significantly attenuates the amplitude of the ATP response $(100 \mu \mathrm{M}, \mathrm{n}=15)$. Additional treatment with $10 \mu \mathrm{M} L Y 83583(\mathrm{n}=19)$ or KT5823 $(1 \mu \mathrm{M}$, $\mathrm{n}=25$ ) prevents the NO action. Data are means \pm SEM. Single asterisks indicate significantly different from the response to ATP alone $(P<0.05)$. Double asterisks indicate significantly different from the response to ATP in the presence of SNP $(P<0.05)$. For abbreviations, see legend for Figure 1.

Inhibition of cyclic GMP dependent kinase blocks the effect of 8-Br-cyclic GMP on ATP-evoked calcium responses. To explore further the involvement of cyclic GMP-dependent kinase in the action of 8-Br-cyclic GMP, we manipulated this part of the pathway by using two different inhibitors of cGK. Rp-8-Br-cyclic GMP is a competitive inhibitor for cyclic GMP (Zhuo et al., 1994; VanUffelen et al., 1996), and KT5823 is a kinase inhibitor acting at the catalytic site competing with ATP (Kase et al., 1987; Haikala et al., 1997; Zhang et al., 1998). KT5823 preferentially inhibits cGK with a $\mathrm{K}_{\mathrm{i}}$ of $0.23 \mu \mathrm{M}$ in contrast to its $\mathrm{K}_{\mathrm{i}}$ for protein kinase $\mathrm{C}(>4 \mu \mathrm{M})$ and cyclic AMP-dependent kinase and myosin light chain kinase ( $>10 \mu \mathrm{M}$; Kase et al., 1987).

Pretreatment of the cells with $30 \mu \mathrm{M}$ Rp-8-Br-cyclic GMP significantly counteracted the suppressive effect of 8-Br-cyclic GMP without changing the time course of the

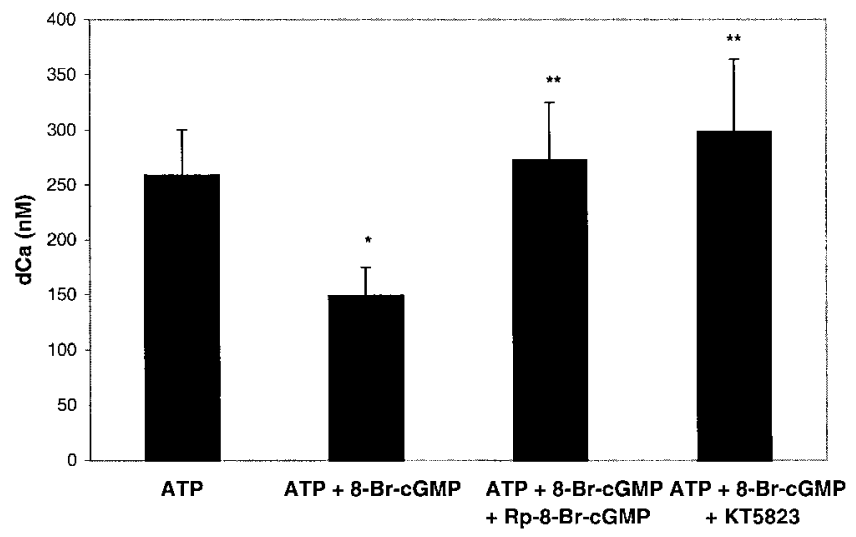

Fig. 10. Effect of 8-Br-cyclic GMP and cGK inhibitors on ATPevoked $\left[\mathrm{Ca}^{2+}\right]_{\mathrm{i}}$ increases. 8-Br-cyclic GMP $(30 \mu \mathrm{M}, \mathrm{n}=12)$ significantly attenuates the amplitude of the ATP response $(100 \mu \mathrm{M}, \mathrm{n}=$ 15). Additional treatment with $100 \mu \mathrm{M}$ Rp-8-Br-cyclic GMP $(\mathrm{n}=10)$ or $1 \mu$ M KT5823 $(\mathrm{n}=10)$ inhibits the action of 8-Br-cyclic GMP, and the amplitude of the ATP response is normal. Data are means \pm SEM. Single asterisks indicate significantly different from the response to ATP alone $(P<0.05)$. Double asterisks indicate significantly different from the response to ATP in the presence of 8-Br-cGMP $(P<0.05)$. For abbreviations, see legend for Figure 1.

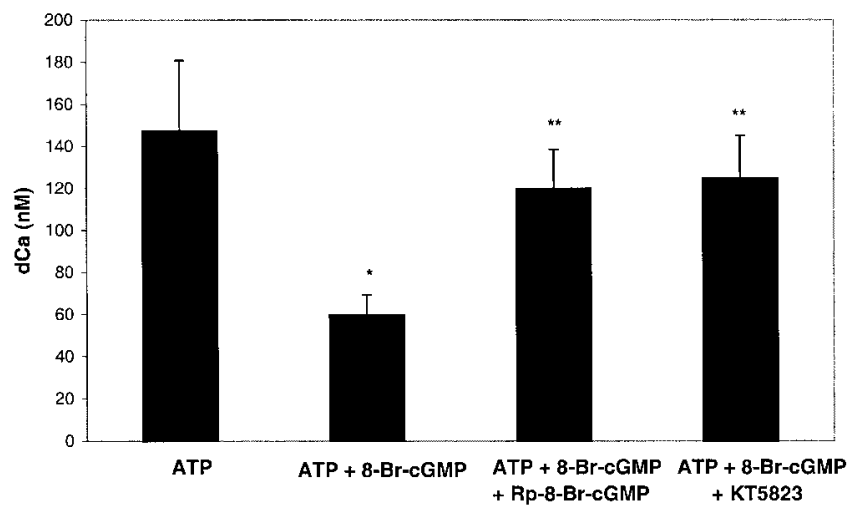

Fig. 11. Effect of 8-Br-cyclic GMP and cGK inhibitors on ATPevoked $\left[\mathrm{Ca}^{2+}\right]_{\mathrm{i}}$ increases in calcium-free medium. 8-Br-cyclic GMP (30 $\mu \mathrm{M}, \mathrm{n}=24)$ significantly attenuates the amplitude of the ATP response $(100 \mu \mathrm{M}, \mathrm{n}=13)$. Additional treatment with $100 \mu \mathrm{M}$ Rp-8$\operatorname{Br}$-cyclic GMP $(n=10)$ or $1 \mu$ M KT5823 $(n=12)$ inhibits the action of 8-Br-cyclic GMP, and the amplitude of the ATP response is normal. Data are means \pm SEM. Single asterisks indicate significantly different from the response to ATP alone $(P<0.05)$. Double asterisks indicate significantly different from the response to ATP in the presence of 8 -Br-cGMP $(P<0.05)$. For abbreviations, see legend for Figure 1 .

response. The amplitude of ATP-evoked $\left[\mathrm{Ca}^{2+}\right]_{\mathrm{i}}$ increase was $273 \pm 52 \mathrm{nM}(\mathrm{n}=10)$ compared with the treatment with 8-Br-cyclic GMP alone (149 $\pm 26 \mathrm{nM}, \mathrm{n}=12$; Fig. 10).

Likewise, preincubation with $1 \mu \mathrm{M}$ KT5823 reversed the suppressive effect of 8-Br-cyclic GMP without changing the time course of the response. The amplitude of the response was $298 \pm 66 \mathrm{nM}(\mathrm{n}=10)$, significantly higher than the response in the presence of 8-Br-cyclic GMP only $(P<0.05$, Fig. 10).

An analogous series of experiments was carried out in $\mathrm{Ca}^{2+}$-free medium. The amplitude of the ATP-evoked 
$\mathrm{Ca}^{2+}$ response was attenuated by 8-Br-cyclic GMP (see above) and significantly restored by cGK inhibitors. The amplitude of the ATP response was $120 \pm 19 \mathrm{nM}(\mathrm{n}=10$, $P<0.05$, Fig. 11) after the combined incubation of $8-\mathrm{Br}-$ cyclic GMP with Rp-8-Br-cyclic GMP and $125 \pm 21 \mathrm{nM}$ after 8-Br-cyclic GMP with KT5823 $(\mathrm{n}=12, P<0.05$, Fig. 11). These amplitudes were significantly higher than those for ATP responses in the presence of 8-Br-cyclic GMP alone $(60 \pm 10 \mathrm{nM}, \mathrm{n}=24)$.

\section{Inhibition of the NO/cGMP/cGK pathway restores ATP-evoked calcium increases in Deiters' cells}

Inhibition of guanylyl cyclase reverses the effect of NO donors on ATP-induced calcium increases. To probe whether the attenuation of the ATP response by NO was mediated by soluble isoforms of guanylyl cyclase (sGC), we blocked sGC activity with LY83583 (Schmidt et al., 1985; Mulsch et al., 1988). Because the $K_{i}$ of LY83583 is $2 \mu \mathrm{M}$, we used $10 \mu \mathrm{M}$ as a bath concentration. In the presence of DEA-NO $(0.1 \mu \mathrm{M})$, additional treatment with $10 \mu \mathrm{M}$ LY83583 restored the amplitude of the ATPinduced $\left[\mathrm{Ca}^{2+}\right]_{\mathrm{i}}$ increase without changing the time course (Fig. 7B). The amplitude of the ATP response in the presence of both DEA-NO and LY83583 and was $157 \pm 24 \mathrm{nM}$ (n $=15, P<0.05$, Fig. 8) and significantly higher than the ATP response in the presence of DEA-NO only $(20 \pm 7 \mathrm{nM}$, $\mathrm{n}=15$ ).

The effect of the other NO donor, SNP, was likewise counteracted by LY83583. The ATP response in the combined incubation was $204 \pm 29 \mathrm{nM}(\mathrm{n}=19$, Fig. 9), significantly higher than in the incubation with SNP only $(91 \pm 17 \mathrm{nM}, \mathrm{n}=25, P<0.05)$.

Inhibition of cGK counteracts the effect of NO donors on ATP-induced calcium increases. To probe whether the attenuation of the ATP response by NO also involved cGK, we measured the ATP-responses of the cells in the presence of both NO donors and a cGK inhibitor (KT5823; Fig. 7C). The amplitude of the response to ATP stimulation in the combined incubation with KT5823 $(1 \mu \mathrm{M})$ and DEA-NO $(0.1 \mu \mathrm{M})$ was $300 \pm 71 \mathrm{nM}(\mathrm{n}=13$, Fig. 8). This value was significantly higher than the ATP-response in the presence of DEA-NO only ( $20 \pm 7 \mathrm{nM}, \mathrm{n}=15)$.

KT5823 likewise counteracted the effect of the other NO donor, i.e., SNP. The amplitude of the ATP-response in combined incubations with KT5823 and SNP $(100 \mu \mathrm{M})$ was $166 \pm 21 \mathrm{nM}(\mathrm{n}=25$, Fig. 9), significantly higher than in the presence of SNP alone (91 $\pm 17 \mathrm{nM}, \mathrm{n}=25)$.

\section{The NO/cGMP/cGK pathway attenuates ATP- evoked calcium increases in Hensen's cells}

To ascertain whether the NO/cyclic GMP pathway may also operate in Hensen's cells, two key experiments were performed based on the studies in Deiters' cells. To probe cyclic GMP involvement, we used the activator 8-Br-cyclic GMP; to probe protein kinase G involvement, we used the inhibitor KT5823.

When Hensen's cells were incubated in HBSS with 8-Br-cyclic GMP (30 $\mu \mathrm{M})$ for 30 minutes before ATP stimulation, the amplitude of the ATP-evoked $\left[\mathrm{Ca}^{2+}\right]_{\mathrm{i}}$ response was significantly attenuated to $52 \pm 19 \mathrm{nM}(\mathrm{n}=8 ; P<$ $0.05 a$, Fig. 12). Pretreatment of the cells with $1 \mu \mathrm{M}$ KT5823 counteracted the suppressive effect of 8-Br-cyclic GMP without changing the time course of the response.

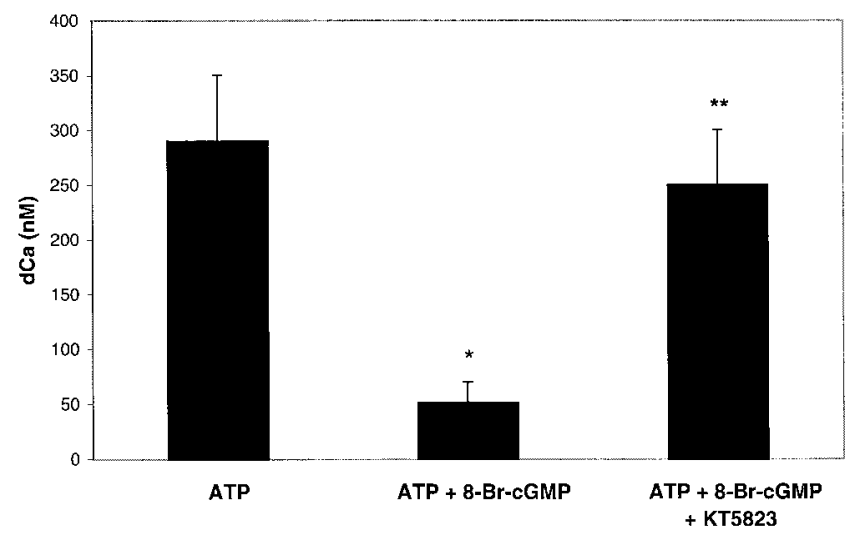

Fig. 12. Effect of 8-Br-cGMP and KT5823 on ATP-evoked $\left[\mathrm{Ca}^{2+}\right]_{\mathrm{i}}$ increases in Hensen's cells. 8-Br-cyclic GMP $(30 \mu \mathrm{M}, \mathrm{n}=8)$ significantly attenuates the amplitude of the ATP response $(100 \mu \mathrm{M}, \mathrm{n}=$ 13). The additional presence of $1 \mu \mathrm{M}$ KT5823 $(\mathrm{n}=10)$ inhibits the action of 8-Br-cyclic GMP, and the amplitude of the response to ATP is normal. Data are means \pm SEM. Single asterisks indicate significantly different from the response to ATP alone $(P<0.05)$. Double asterisks indicate significantly different from the response to ATP in the presence of 8 -Br-cGMP $(P<0.05)$.

The amplitude of the ATP-evoked $\left[\mathrm{Ca}^{2+}\right]_{\mathrm{i}}$ increased to $250 \pm 51(\mathrm{n}=10)$ compared with $52 \pm 19 \mathrm{nM}$ for the application of 8-Br-cyclic GMP alone ( $\mathrm{n}=13$, Fig. 12).

\section{DISCUSSION}

\section{Calcium signaling in cochlear Deiters' cells}

The results presented here indicate that the NO/cGMP/ cGK pathway participates in $\left[\mathrm{Ca}^{2+}\right]_{\mathrm{i}}$ regulation in the mammalian auditory system. Although several mechanisms are known to mediate calcium increases in cochlear cells such as voltage-gated and ligand-gated channels, no other attenuation mechanisms have yet been documented in functional studies in the inner ear.

Nitric oxide synthase (NOS) was the first enzyme of the NO/cGMP/cGK pathway to be demonstrated in the mammalian cochlea (Fessenden et al., 1994, 1997; Zdanski et al., 1994; Yamane et al., 1997). The constitutive neuronal isoform of NOS is present in nerve fibers innervating inner and outer hair cells and spiral ganglion cells (Fessenden et al., 1994). Subsequently sGC and cGK were localized in supporting structures (Deiters' cells, Hensen's cells, inner and outer pillar cells) of the organ of Corti (Fessenden and Schacht, 1997; Tian et al., 1999). The functional role of this pathway, however, remained speculative (Fessenden and Schacht, 1998).

We can now postulate that all segments of the NO/ cGMP/cGK pathway participate in a calcium-attenuating mechanism in supporting cells. First, two different NO donors clearly reduce the amplitude of the ATP-evoked calcium signal, whereas a NO-depleted DEA-NO solution is inactive. Second, the participation by sGC is suggested by the results showing that inhibition of sGC by LY83583 counteracts the effect of NO donors on ATP-induced calcium increases. The involvement of cGK is also shown by the fact that its inhibitor, KT5823, counteracts the attenuation by NO donors. Finally, the attenuating effect of the 
sGC stimulator 8-Br-cGMP and its inhibition by KT5823 connects the effects of NO and cyclic GMP to cGK.

The demonstration that the attenuating effect of NO on $\left[\mathrm{Ca}^{2+}\right]_{\mathrm{i}}$ in Deiters' and Hensen's cells is mediated by means of cyclic GMP and the ensuing activation of cGK is in good agreement with the action of NO in other tissues. cGK plays a crucial role in mediating the inhibitory effects of NO on $\mathrm{Ca}^{2+}$ release and influx in muscle (Cornwell and Lincoln, 1989; Chen and Rembold, 1992b; Andrade et al., 1998), platelets (Geiger et al., 1992), PC12 cells (Clementi et al., 1995b), NIH-3T3 fibroblasts (Clementi et al., 1995a), pancreatic acinar cells (Pandol and SchoeffieldPayne, 1990), and CHO cells (Ruth et al., 1993).

Although the target(s) of phosphorylation by $\mathrm{cGK}$ in cochlear supporting cells remain to be established, our results point to certain possibilities. The experiments in calcium-free medium are compatible with an inhibition of $\mathrm{Ca}^{2+}$ release from internal $\mathrm{Ca}^{2+}$ stores. This reduction may be mediated by a cGK-dependent phosphorylation of $\mathrm{IP}_{3}$ receptors (Komalavilas and Lincoln, 1996) or a decrease of $\mathrm{IP}_{3}$ generation, an action of $\mathrm{NO}$ first reported in aortic strips and platelets (Felbel et al., 1988; Karaki et al., 1988; Cornwell and Lincoln, 1989; Nguyen et al., 1991). Both histochemical and functional evidence place $\mathrm{IP}_{3}$ receptors in Deiters' and Hensen's cells (Tian et al., 1999). However, this may not be the only site of action. Other targets possibly regulated by cyclic GMP and cGK are L-type voltage-gated calcium channels (Nishimura et al., 1992; Meriney et al., 1994). Yet another calciumattenuating mechanism can occur by means of phosphorylation of phospholamban by cGK, resulting in its dissociation from and activation of a $\mathrm{Ca}^{2+}$-ATPase (Cornwell and Lincoln, 1989). Further studies on protein phosphorylation in the cochlea should shed more light on this question.

\section{Neurotransmitter action on cochlear supporting cells}

ATP produces a robust and wide-spread $\left[\mathrm{Ca}^{2+}\right]_{\mathrm{i}}$ signal in supporting cells. This finding is in stark contrast to the highly localized response seen in outer hair cells (Mammano et al., 1999). Supporting cells in the organ of Corti possess ionotropic $\left(\mathrm{P}_{2} \mathrm{X}\right)$ and G-protein coupled metabotropic $\left(\mathrm{P}_{2} \mathrm{Y}\right)$ receptors (Dulon et al., 1993; Chen and Bobbin, 1998). On the basis of the attenuation of the ATP response in calcium-free media, both types of receptors may be activated in our experiments resulting in calcium influx and release from intracellular stores. However, the potential participation of stretch-activated calcium channels is ruled out by the fact that neither Deiters' nor Hensen's cells responded to the puff application of HBSS alone.

The physiologic source of ATP in the organ of Corti remains open. ATP could be coreleased with the putative neurotransmitters of the afferent (glutamate) and/or efferent (acetylcholine, GABA) systems, which innervate the sensory cells (Zimmermann, 1994; Burnstock, 1997). Recent anatomic studies have shown that both Deiters' and Hensen's cells are also innervated (Burgess et al., 1997; Fechner et al., 1998), but the neurotransmitters are unknown. ATP is present in endolymph and may influence cochlear function from this compartment (Munoz et al., 1995a; Kirk and Yates, 1998). Finally, ATP may be released from cells during tissue injury (Gordon, 1986) and in the inner ear, brief hypoxia caused a doubling of peril- ymphatic ATP concentration in vivo (Munoz et al., 1995b). Regardless of its source, ATP is an established signaling molecule in the cochlea and may modulate the transduction process through interaction with $\mathrm{P}_{2}$ receptors (Skellett et al., 1997; Chen et al., 1998; Bobbin et al., 1998) either on supporting cells or hair cells (Nakagawa et al., 1990; Housley et al., 1992; Housley, 1997).

In contrast to ATP, the origin of NO can be more clearly delineated. Neuronal nitric oxide synthase has been localized in both afferent and efferent nerve fibers, suggesting that NO as a gaseous and diffusible molecule could affect the sensory cells as well as the supporting cells (Fessenden et al., 1994; Zdanski et al., 1994; Fessenden and Schacht, 1998). Because both ATP and NO are neuromodulators, their complimentary action represents an intriguing regulatory loop of supporting cell physiology.

\section{Role of supporting cells in the cochlea}

The role of supporting cells in the cochlea is largely speculative because biochemical and physiological studies have centered almost exclusively on the sensory cells. Recently, evidence has been accumulating that supporting cells play a more active role than has previously been recognized. The fact of their innervation and of the neurotransmitter-mediated regulation of calcium homeostasis suggests them as part of a complex regulatory mechanism in the cochlea. Although the analysis of isolated cells, as in this study, has distinct advantages, it also has its limitations. Supporting cells are interconnected by numerous gap junctions (Jahnke, 1975; Gulley and Reese, 1976), and the isolation procedure disrupts intercellular communication. This aspect of supporting cell physiology, therefore, cannot be addressed in the single-cell preparation.

Both Hensen's and Deiters' cells have a very specialized morphology. Hensen's cells are characterized by lipid droplets and microvilli that may facilitate ion exchange and influence fluid and ion contents in the organ of Corti (Slepecky, 1996). Variations in $\left[\mathrm{Ca}^{2+}\right]_{\mathrm{i}}$ could modulate the (as yet unknown) homeostatic processes in which Hensen's cells participate.

Deiters' cells contain microfilaments and microtubules and are considered a structural reinforcement of the basilar membrane. They possess an apical "stalk" (phalangeal process, Fig. 2A) that attaches to an outer hair cell and a cup region that ensconces the base of another outer hair cell. Dulon et al. (1994) showed a small movement of the head of the phalangeal process and an increase of its stiffness in response to an increase in $\left[\mathrm{Ca}^{2+}\right]_{\mathrm{i}}$. Outer hair cells also undergo shape changes in response to calcium, and Deiters' cells could contribute additional mechanical forces influencing the basilar membrane. In fact, stimulation by intense sound imparts dynamic structural changes on the organ of Corti, which appear to be mediated by outer hair cells, Deiters' and Hensen's cells (Flock et al., 1999). The NO/cGMP/cGK pathway could play a crucial role in regulating the underlying calcium signals.

\section{ACKNOWLEDGMENT}

The authors thank Dr. Su-Hua Sha for contributing the photo of the Hensen's cell. 


\section{LITERATURE CITED}

Ahmad I, Barnstable CJ. 1993. Differential laminar expression of particulate and soluble guanylate cyclase genes in rat retina. Exp Eye Res $56: 51-62$.

Andrade FH, Reid MB, Allen DG, Westerblad H. 1998. Effect of nitric oxide on single skeletal muscle fibres from the mouse. J Physiol (Lond) 509:577-586.

Ashmore JF, Ohmori H. 1990. Control of intracellular calcium by ATP in isolated outer hair cells of the guinea-pig cochlea. J Physiol (Lond) 428:109-131.

Berridge MJ. 1998. Neuronal calcium signaling. Neuron 21:13-26.

Berridge M, Lipp P, Bootman M. 1999. Calcium signalling. Curr Biol 9:R157-159

Bobbin RP, Chen C, Nenov AP, Skellett RA. 1998. Transmitters in the cochlea. The quadratic distortion product and its time varying response may reflect the function of ATP in the cochlea. In: Berlin CI, editor. Acoustical emissions: basic science and clinical applications. San Diego. CA: Singular. p 61-83.

Burgess BJ, Adams JC, Nadol JB Jr. 1997. Morphologic evidence for innervation of Deiters' and Hensen's cells in the guinea pig. Hear Res 108:74-82.

Burnstock G. 1997. The past, present and future of purine nucleotides as signaling molecules. Neuropharmacology 36:1127-1139.

Chen C, Bobbin RP. 1998. $\mathrm{P}_{2} \mathrm{X}$ receptors in cochlear Deiters' cells. Br J Pharmacol 124:337-344.

Chen C, Skellett RA, Fallon M, Bobbin RP. 1998. Additional pharmacological evidence that endogenous ATP modulates cochlear mechanics. Hear Res 118:47-61.

Chen XL, Rembold CM. 1992. Cyclic nucleotide-dependent regulation of $\mathrm{Mn}^{2+}$ influx, $\left[\mathrm{Ca}^{2+}\right]_{\mathrm{i}}$, and arterial smooth muscle relaxation. Am J Physiol 263:C468-C473.

Clementi E. 1998. Role of nitric oxide and its intracellular signaling pathways in the control of $\mathrm{Ca}^{2+}$ homeostasis. Biochem Pharmacol 55:713718.

Clementi E, Sciorati C, Riccio M, Miloso M, Nistico G. 1995a. Nitric oxide action on growth factor-elicited signals. Phosphoinositide hydrolysis and $\left[\mathrm{Ca}^{2+}\right]_{\mathrm{i}}$ responses are negatively modulated via a cGMP-dependent protein kinase I pathway. J Biol Chem 270:22277-22282.

Clementi E, Vecchio I, Sciorati C, Nistico G. 1995b. Nitric oxide modulation of agonist-evoked intracellular $\mathrm{Ca}^{2+}$ release in neurosecretory PC-12 cells: inhibition of phospholipase $\mathrm{C}$ activity via cyclic GMP-dependent protein kinase I. Mol Pharmacol 47:517-524.

Corbin JD, Ogreid D, Miller JP, Suva RH, Jastorff B, Doskeland SO. 1986. Studies of cGMP analog specificity and function of the two intrasubunit binding site of cGMP-dependent protein kinase. J Biol Chem 261: $1208-1214$.

Cornwell TL, Lincoln TM. 1989. Regulation of intracellular $\mathrm{Ca}^{2+}$ levels in cultured vascular smooth muscle cells. Reduction of $\mathrm{Ca}^{2+}$ by atriopeptin and 8-bromo-cyclic GMP is mediated by cyclic GMP-dependent kinase. J Biol Chem 264:1146-1155.

Cudeiro J, Rivadulla C. 1999. Sight and insight - on the physiological role of nitric oxide in the visual system. Trends Neurosci 22:109-116.

Dellacorte C, Kalinoski DL, Huque T, Wysocki L, Restrepo D. 1995. NADPH diaphorase staining suggests localization of nitric oxide synthase within mature vertebrate olfactory neurons. Neuroscience 66: $215-225$.

Doi T, Ohmori H. 1993. Acetylcholine increases intracellular $\mathrm{Ca}^{2+}$ concentration and hyperpolarizes the guinea-pig outer hair cell. Hear Res 67:179-188.

Dulon D, Zajic G, Schacht J. 1990. Increasing intracellular free calcium induces circumferential contractions in isolated outer hair cells. J Neurosci 10:1388-1397.

Dulon D, Moataz R, Mollard P. 1993. Characterization of $\mathrm{Ca}^{2+}$ signals generated by extracellular nucleotides in supporting cells of the organ of Corti. Cell Calcium 14:245-254.

Dulon D, Blanchet C, Laffon E. 1994. Photo-released intracellular $\mathrm{Ca}^{2+}$ evokes reversible mechanical responses in supporting cells of the guinea-pig organ of Corti. Biochem Biophys Res Commun 201:12631269.

Fechner FP, Burgess BJ, Adams JC, Liberman MC, Nadol JB Jr. 1998. Dense innervation of Deiters' and Hensen's cells persists after chronic deafferentation of guinea pig cochleas. J Comp Neurol 400:299-309.

Felbel J, Trockur B, Ecker T, Landgraf W, Hofmann F. 1988. Regulation of cytosolic calcium by cyclic AMP and cyclic GMP in freshly isolated smooth muscle cells from bovine trachea. J Biol Chem 263:1676416771.

Fessenden JD, Schacht J. 1997. Localization of soluble guanylate cyclase activity in the guinea pig cochlea suggests involvement in regulation of blood flow and supporting cell physiology. J Histochem Cytochem 45: 1401-1408.

Fessenden JD, Schacht J. 1998. The nitric oxide/cyclic GMP pathway: a potential major regulator of cochlear physiology. Hear Res 118:168176.

Fessenden JD, Coling DE, Schacht J. 1994. Detection and characterization of nitric oxide synthase in mammalian cochlea. Brain Res 668:9-15.

Flock Å, Flock B, Fridberger A, Scarfone E, Ulfendahl M. 1999. Supporting cells contribute to control of hearing sensitivity. J Neurosci 19:44984507.

Fridberger A, Flock Å, Ulfendahl M, Flock B. 1998. Acoustic overstimulation increases outer hair cell $\mathrm{Ca}^{2+}$ concentrations and causes dynamic contraction of the hearing organ. Proc Natl Acad Sci USA 95:71277132 .

Geiger J, Nolte C, Butt E, Sage SO, Walter U. 1992. Role of cyclic GMP and cyclic GMP-dependent protein kinase in nitrovasodilator inhibition of agonist-evoked calcium elevation in human platelets. Proc Natl Acad Sci USA 89:1031-1035.

Gordon JL. 1986. Extracellular ATP: effects, sources, and fate. Biochem J 233:309-319.

Gryglewski RJ, Korbut R, Kalecinska A, Zembowicz A. 1989. Interaction between stimulators of adenylate and guanylate cyclases in human leukocytes, platelets and arteries. Int J Tissue React 11:269-275.

Gulley RL, Reese TS. 1976. Intercellular junctions in the reticular lamina of the organ of Corti. J Neurocytol 5:479-507.

Haikala H, Kaheinen P, Levijoki J, Linden IB. 1997. The role of cAMP- and cGMP-dependent kinases in the cardiac actions of the new calcium sensitizer, levosimenden. Cardiovasc Res 34:536-546.

Housley GD. 1997. Extracellular nucleotide signaling in the inner ear. Mol Neurobiol 16:21-49.

Housley GD, Greenwood D, Ashmore JF. 1992. Localization of cholinergic and purinergic receptor on outer hair cells isolated from the guinea-pig cochlea. Proc R Soc Lond B 249:265-273.

Jahnke K. 1975. The fine structure of freeze-fractured intercellular junctions in the guinea pig inner ear. Acta Otolaryngol Suppl (Stockh) 336:1-40.

Kannan MS, Prakash YS, Johnson DE, Sieck GC. 1997. Nitric oxide inhibits calcium release from sarcoplasmic reticulum of porcine tracheal smooth muscle cells. Am J Physiol 272:L1-L7

Karaki H, Sato K, Ozaki H, Murakami K. 1988. Effects of sodium nitroprusside on cytosolic calcium level in vascular smooth muscle. Eur J Pharmacol 156:259-266

Kase H, Iwahashi K, Nakanishi S, Matsuda Y, Yamada K, Takahashi M, Murakata C, Sato A, Kaneko M. 1987. K-252 compounds, novel and potent inhibitors of protein kinase $\mathrm{C}$ and cyclic nucleotide-dependent protein kinases. Biochem Biophys Res Commun 142:436-440.

Kirk DL, Yates GK. 1998. ATP in endolymph enhances electrically-evoked oto-acoustic emissions from the guinea pig cochlea. Neurosci Lett 250: $149-152$.

Komalavilas P, Lincoln TM. 1996. Phosphorylation of the inositol 1,4,5triphosphate receptor: cyclic GMP-dependent protein kinase mediates cAMP and cGMP dependent phosphorylation in the intact rat aorta. J Biol Chem 271:21933-21938.

Mammano F, Frolenkov GI, Lagostena L, Belyantseva IA, Kurc M, Dodane V, Colavita A, Kachar B. 1999. ATP-induced $\mathrm{Ca}^{2+}$ release in cochlear outer hair cells: localization of an inositol trisphosphate-gated $\mathrm{Ca}^{2+}$ store to the base of the sensory bundle. J Neurosci 19:6918-6929.

Maragos CM, Morley D, Wink DA, Dunams TM, Saavedra JE, Hoffman A, Bove AA, Isaac L, Hrabie JA, Keefer LK. 1991. Complexes of NO with nucleophiles as agents for the controlled biological release of nitric oxide: vasorelaxant effect. J Med Chem 34:3242-3247

Meriney SD, Gray DB, Pilar GR. 1994. Somatostatin induced inhibition of neuronal $\mathrm{Ca}^{2+}$ current modulated by cGMP-dependent protein kinase. Nature 369:336-339.

Mulsch A, Busse R, Liebau S, Forstermann U. 1988. LY83583 interferes with the release of endothelium-derived relaxing factor and inhibits soluble guanylate cyclase. J Pharmacol Exp Ther 247:283-288.

Munoz DJ, Thorne PR, Housley GD, Billett TE, Battersby JM. 1995a Extracellular adenosine 5 '-triphosphate (ATP) in the endolymphatic compartment influences cochlear function. Hear Res 90:106-118.

Munoz DJ, Thorne PR, Housley GD, Billett TE. 1995b. Adenosine 5'- 
triphosphate (ATP) concentrations in the endolymph and perilymph of the guinea-pig cochlea. Hear Res 90:119-125.

Nakagawa T, Akaike N, Kimitsuki T, Komune S, Arima T. 1990. ATPinduced current in isolated outer hair cells of the guinea pig cochlea. J Neurophysiol 63:1068-1074.

Nguyen BL, Saitoh M, Ware JA. 1991. Interaction of nitric oxide and cGMP with signal transduction in activated platelets. Am J Physiol 261: H1043-H1052.

Nishimura J, Moreland S, Ahn HY, Kawase T, Moreland RS, Vanbreemen C. 1992. Endothelin increases myofilament $\mathrm{Ca}^{2+}$ sensitivity in alpha toxin permeabilized rabbit mesenteric artery. Circ Res 71:951-959.

Pandol SJ, Schoeffield-Payne MS. 1990. Cyclic GMP regulates free cytosolic calcium in the pancreatic acinar cell. Cell Calcium 11:477-486.

Ruth P, Wang G-X, Boekhoff I, May B, Pfeifer A, Penner R, Korth M, Breer H, Hofmann F. 1993. Transfected cyclic GMP-dependent kinase suppresses calcium transients by inhibition of inositol 1, 4, 5-triphosphate production. Proc Natl Acad Sci USA 90:2623-2627.

Schmidt MJ, Sawyer BD, Truex LL, Marshall WS, Fleisch JH. 1985. LY83583: an agent that lowers intracellular level of cyclic guanosine 3',5'-monophosphate. J Pharmacol Exp Ther 232:764-769.

Shah AM, Spurgeon HA, Sollott SJ, Talo A, Lakatta EG. 1994. 8-Bromocyclic GMP reduced the myofilament response to $\mathrm{Ca}^{2+}$ in intact cardiac myocyte. Circ Res 74:970-978.

Skellett RA, Chen C, Fallon M, Nenov AP, Bobbin RP. 1997. Pharmacological evidence that endogenous ATP modulates cochlear mechanics. Hear Res 111:42-54.

Slepecky NB. 1996. Structure of the mammalian cochlea. In: Dallos P, Popper AN, Fay RR, editors. The cochlea. New York: Springer. p $44-129$

Sugasawa M, Erostegui C, Blanchet C, Dulon D. 1996. ATP activates a cation conductance and $\mathrm{Ca}^{2+}$-dependent $\mathrm{Cl}^{-}$conductance in Hensen's cell of guinea pig cochlea. Am J Physiol 271:C1817-C1827.

Tian F, Fessenden JD, Schacht J. 1999. Cyclic GMP-dependent protein kinase-I in the guinea pig cochlea. Hear Res 131:63-70.

VanUffelen BE, de Koster BM, Van de Broek PJ, VanStevenninck J, Elferink JGR. 1996. Modulation of neutrophil migration by exogenous gaseous nitric oxide. J Leukoc Biol 60:94-100.

Yamamoto R, Bredt DS, Snyder SH, Stone RA. 1993. The localization of nitric oxide synthase in the rat eye and related cranial ganglia. Neuroscience 54:189-200.

Yamane H, Takayama M, Konishi K, Iguchi H, Shibata S, Sunami K, Nakai Y. 1997. Nitric oxide synthase and contractile protein in the rat cochlear lateral wall: possible role of nitric oxide in regulation of strial blood flow. Hear Res 108:65-73.

Zajic G, Schacht J. 1987. Comparison of isolated outer hair cells from five mammalian species. Hear Res 22:83-90.

Zdanski CJ, Prazma J, Petrusz P, Grossman G, Raynor E, Smith TL, Pillsbury HC. 1994. Nitric oxide synthase is an active enzyme in the spiral ganglion cells of the rat cochlea. Hear Res 79:39-47.

Zhang W, Han XV, Wong SM, Takeuchi H. 1998. Effects of inhibitors for intracellular signal transduction systems on the inward current produced by GABA in a snail neuron. Gen Pharmacol 30:221-225.

Zhuo M, Hu Y, Schiltz C, Kandel ER, Hawkins RD. 1994. Role of guanylyl cyclase and cyclic GMP-dependent protein kinase in long-term potentiation. Nature 368:635-639.

Zenner HP, Zimmermann U, Schmitt U. 1985. Reversible contraction of isolated mammalian cochlear hair cells. Hear Res 18:127-133.

Zimmermann H. 1994. Signalling via ATP in the nervous system. Trends Neurosci 17:420-426. 